\title{
MECHANISM OF FINANCIAL AND CREDIT SUPPORT OF ENTREPRENEURIAL ACTIVITIES
}

\author{
Zhanna Kononenko ${ }^{1 *}$, ORCID: 0000-0003-0074-8249, \\ Oleksandra Kuzmenko ${ }^{2}$, ORCID: 0000-0002-0660-1953, \\ Kateryna Pylypenko ${ }^{1}$, ORCID: 0000-0003-3170-1208 \\ ${ }^{1}$ Poltava state agrarian Academy, Ukraine \\ ${ }^{2}$ Poltava University of Economics and Trade, Ukraine \\ ${ }^{3}$ Poltava state agrarian Academy, Ukraine \\ *Corresponding author: Zhanna Kononenko,konon_ukr@ukr.net
}

Received: 11. 09. 2020

Accepted: 11. 10. 2020

\begin{abstract}
The problematic aspects of the financial and credit mechanism of business activity are considered. Some factors of formation of financial interrelations at the micro level and their interaction at the macro level are investigated. The problem areas of entrepreneurship are emphasized. The systemic factors of sources of financial resources in the business sector are generalized. Attention is paid to the need to develop and improve the financial subsystem of entrepreneurial activity. Peculiarities of supporting potential innovative implementation are investigated.
\end{abstract}

Key words: resources, assets, financial mechanism, financial flows, financial condition, entrepreneurship, financial support, business activity, financial assistance, financial and economic relations.

Rezumat. În articol sunt examinate unele aspecte problematice ale mecanismului financiar și de creditare a activității comerciale. Au fost investigați unii factori de formare a interrelațiilor financiare la nivel micro și interacțiunea lor la nivel macro. Sunt subliniate domeniile problematice ale antreprenoriatului. Factorii sistemici ai surselor de resurse financiare din sectorul de afaceri au fost generalizați. Se acordă atenție necesității dezvoltării și îmbunătățirii subsistemului financiar al activității antreprenoriale. Sunt cercetate particularitățile sprijinirii unei potențiale implementări inovatoare.

Cuvinte cheie: resurse, active, mecanism financiar, fluxuri financiare, situație financiară, antreprenoriat, sprijin financiar, activitate comercială, asistență financiară, relații financiare și economice.

\section{Introduction}

Financial and credit support for various enterprises in any industry today is becoming an objective reality in market conditions. Since the need to replenish the working capital of the enterprise, to modernize fixed assets; in attracting the latest technologies, raw materials, manufacturing new products; in raising funds necessary to advance the management process [1]. A financial and credit mechanism that contributes to the development of entrepreneurial activity in these conditions should be a complex of financial methods, such as planning, 
management, control, provision, and also act as a lever of influence on its development. A financial mechanism in the narrow sense refers to sources of financial and credit support, such as self-financing, for example, lending and budget financing, as well as a model for regulating financial flows. The financial and credit mechanism includes legal, methodological, organizational, information-software and information-analytical support.

Summing up the results of the dialogue on discussion platforms between government officials and entrepreneurs, we can conclude that there are a number of problems, and one of the most acute problems of most enterprises is the problem of financing various business projects, finding and raising funds, promotion of flows, lending to the business management process. The possibility of developing a financial subsystem to support new activities, especially at the initial stage of innovation, due to the high commercial risk of investing in existing innovations, the need for large financial costs, as well as a long period (result) of return on investment [2].

Public financing of entrepreneurship is considered non-market and therefore impractical. But in practice, in many developed countries, subsidies remain one of the most common ways of financial and credit mechanism to promote business development. Direct targeted state support is provided to those enterprises whose activities are important for the development of the state economy or are of paramount importance. If entrepreneurs of different ranks get quick access to various financial, material and technical resources, the process of their functioning will change dramatically in the necessary direction of business development, and many tasks of the state business support program will be solved automatically.

In our country, due to lack of budget funds, there is almost no targeted financial assistance, and for the development of enterprises-firms own funds are not enough, so loans are the main source of replenishment of financial resources. Therefore, the primary task in solving this problem should be to study the situation of the financial and credit mechanism to promote entrepreneurship. In Ukraine, financial and credit support is two-tier, Figure 1.

At this stage of economic reforms in Ukraine, it is necessary to create an effective financial and credit mechanism to promote business development. This requires: have non-profit microfinance institutions that would have the right to provide loans to enterprises of various types of business; create structural subdivisions or small sectors in banking institutions that would study the demand for microloans and the history of enterprises; to active financing of small and medium business enterprises; to form a system of guaranteeing microcredits by local authorities and various funds; to promote lending to business entities that produce products for export or produce products that reduce the number of imports; develop national, and with them regional, business microcredit programs by the non-banking system (for example, credit unions and insurance and leasing institutions, etc.); to expand the system of training and retraining of entrepreneurs in microcredit.

As for the measures implemented in developed countries in the formation of financial and credit regulation, it is a reduction in producer costs or a reduction in the discount rate by the Central Bank. The basic principles of formation of the financial and credit mechanism should be systemic and comprehensive, the principles of sufficiency and diversification, comprehensive validity with predictability and, of course, transparency.

Banking institutions are in no hurry to deal with small businesses. There are many reasons for this. This can be a lack of collateral, a small loan share and a short repayment period, in the medium term it is a significant risk and a small profit in terms of lending to large borrowers. Regarding the types of bank loans, the mechanism for obtaining them is divided into: transfer, overdraft, pawnshop, seasonal, open credit line, revolver, oncol, form, mortgage, consortium. Thus, the rates of credit institutions operating in the markets for a short period of time (for example, a year) are very high for small businesses, which makes bank loans unattainable for this sector of the economy. 


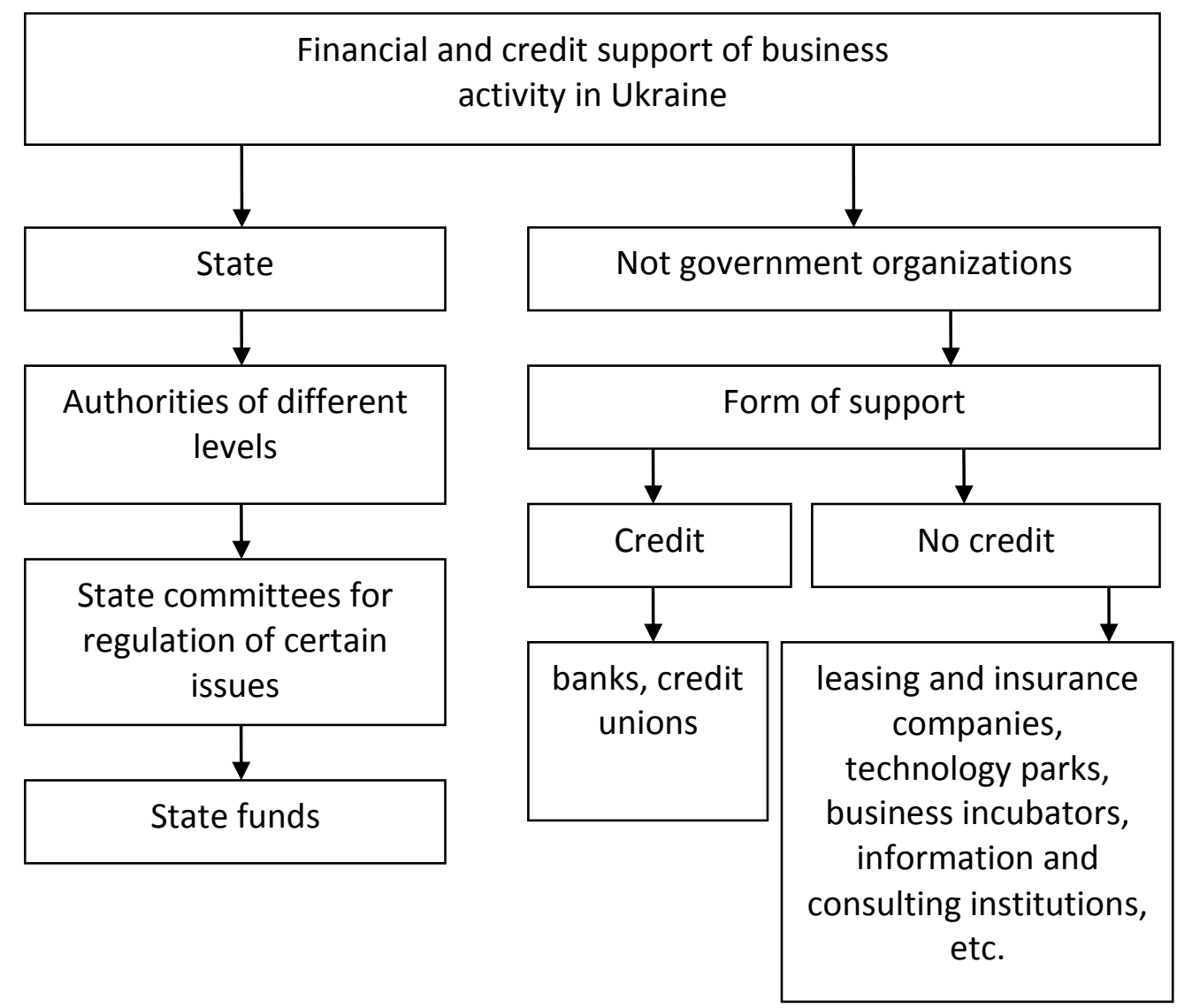

Figure 1. Two-level system of financial and credit support for entrepreneurship. Source: own development.

The solution is to enter into loan agreements with financial intermediaries related to the nonbanking sector, such as credit unions, public and private support funds, international organizations [1]. There is even the concept of «micro-enterprise», but the definition of this term is very heterogeneous, as it depends on the size of the existing enterprise, namely the number of employees, sales and the need for small loans. Taking into account the world experience, micro-enterprise and microbusiness are defined as:

- private property, when the enterprise belongs to one owner or family and has less than ten employees, and, as a rule, it is serviced by the family or owners;

- an enterprise that provides part-time or self-employment to provide additional sources of family income. Thus, according to this definition of a micro-enterprise include most of the existing small enterprises in Ukraine [3]. Microcredit, which is used as a strategy for economic growth and development, stimulates profit-oriented activities, helps businesses balance existing sources of income and helps transform micro-enterprises into the next form of management small business.

Today there is a need for investment for the Ukrainian economy, including the small and medium business segment. You can attract them with the help of levers in the market of financial services and leasing. Leasing is an alternative form of bank lending. From the point of view of the tax sphere, types of lease transactions and leasing transactions are exempt from value added tax. The introduction of leasing will significantly reduce start-up capital for starting and developing a business. Thus, the increase in leasing operations can become a locomotive for the development of small and medium enterprises in our country. Leasing increases the interest in investing private capital in real production, improves the financial condition of producers, which in turn increases the competitiveness of domestic small and medium-sized businesses [4]. 
The above problems allow us to define the relationship between the mechanisms of financial and credit support for business, as a way to harmonize the concepts of «mechanism», "bank lending", "government regulation" and "business». In the economic sense, there are different interpretations of the concept of "mechanism", which is defined as a system of communications, devices, methods that determine the direction of a particular activity. Engaged in entrepreneurial activity, the entrepreneur is guided by commercial gain and acts for profit. In this way, it produces products that bring it profit, attract those means of production that require less cost and are more productive. After all, the main thing for an entrepreneur should be the efficiency of production. But in practice there are motives for entrepreneurs to engage in entrepreneurial activity not only the desire to make a profit, but also the opportunity to realize their abilities in practice, to show their skills, ambitions, professionalism, initiative, creativity and more. Today it is necessary to create simple and clear mechanisms for involving the population in the implementation of their business ideas; to create a state of socio-economic and politicallegal environment that would contribute to the formation and successful development of entrepreneurship, providing freedom and guarantee of the process, which is especially important in a crisis in the economy [5].

Creating a holistic system of state regulation of business relations is a complex and lengthy process. The big role here is the regulatory policy of the state. In a market economy, the introduction of financial regulation is at the forefront, lending is regulated by the relevant vector of state regulatory policy, and the main use of budget funds can be not only direct investment, but also insurance and loan guarantees. Prospects for further research into the mechanisms of financial and credit security of business activities are studies of small and medium business support.

\section{References}

1. Synoverskyi R. L. Lending to small and medium business: problems and prospects. In: Ekonomika ta derzhava, 2016, 9, pp. 72-76.

2. Halunko V., Halunko V., Savyuk M. Foreign experience for financing small and medium business. In: Baltic Journal of Economic Studies. 2018, 4 (5), pp. 40-45.

3. Kalmikov, O.V. Financial and credit mechanism to promote small business. Finance, money circulation, credit. 2015, 27/1. pp. 173-178.

4. Akimova L.M. State regulation of business: foreign experience of cooperation between the state and the business sector [online]. 2018, [accesat 10.10.2020]. Disponibil: https://cyberleninka.ru/article/n/state-regulation-ofbusiness-foreign-experience-of-cooperation-between-the-stateand-the-business-sector.

5. Goncharova V.G. Mechanism of state financial and credit support for small business development. In: Public administration: improvement and development. [online]. 2009, [accesat 10.10.2020]. Disponibil: http://www.dy.nayka.com.ua/?op=1\&z=254 